\title{
Analysis of Utilization of Electricity Renewed From Methane Gas Organic Waste Product
}

\author{
Muhammad Hasbi ${ }^{1}$, Yuspian Gunawan ${ }^{2}$, Jenny Delly $^{3}$, Kadir $^{4}$, Abdul Djohar ${ }^{5}$, Samhuddin $^{6}$, \\ Nanang Endriatno ${ }^{7}$, Adytia Rachman ${ }^{8}$, Lilis Laome ${ }^{9}$ \\ \{m.hasbi@uho.ac.id ${ }^{1}$, yuspiangunawanstmt@gmail.com², \\ jenydelly09@gmail.com ${ }^{3}$, irkadir@gmail.com ${ }^{4}$, joharunhalu@yahoo.com ${ }^{5}$, \\ samhuddinkbn@gmail.com ${ }^{6}$, nanang.endriatno@uho.ac.id ${ }^{7}$, \\ adityarchmn@yahoo.com ${ }^{8}, \underline{\left.\text { lhi2slaome@gmail.com }{ }^{9}\right\}}$
}

Jurusan Mesin Fakultas Teknik Universitas Halu Oleo ${ }^{1,2,3,4,6,7,8}$, Jurusan Elektro Fakultas Teknik Universitas Halu Oleo ${ }^{5}$, Jurusan Matematika Fakultas Matematika dan Ilmu Pengetahuan Alam Universitas Halu Oleo ${ }^{9}$

\begin{abstract}
The aim of the study was to determine the amount of electrical energy generated from methane gas produced from the volume of waste. The research method is carried out by literature review and field surveys, as well as theoretical calculations. Data was collected at the Tempat Pembuangan Akhir (TPA) and Kendari City Sanitation Office, by meeting and interviewing people directly related to the landfill management process, communities in energy independent settlements, as well as in the municipal sanitation office. The results of the study revealed that the energy produced from the Tempat Pembuangan Akhit (TPA) Puuwatu in the daily average was 288,466.5332 kWh. The amount of electrical energy that has been utilized by the Pemukiman Mandiri Energi is $1,080 \mathrm{kWh}$. The untapped energy is $287,386.5332 \mathrm{kWh}$.
\end{abstract}

Keywords: Energy independent settlements, Methane Gas, Organic Waste, Electric Energy.

\section{Introduction}

Improved landfill performance, in addition to increasing the rate of degradation of treated waste and leachate, can also increase the economic value of waste, and support the economic activities of the community. "We also look forward to the role of universities, to support applied research, related to the development of science and technology in the waste sector," said Budi, who also presented the Professors of Waste from ITB, Enri Damanhuri [1]. According to the 2018 World Bank Group estimates, the annual global generation of waste was 1.3 billion tons and was expected to reach approximately 2.2 billion tons by 2025 [2].

From previous research, Kendari City Puwatu Landfill has the potential for electrical energy from methane gas generated from landfill activities. Puwatutan landfill methane gas in 2017 has the potential for electrical energy of 12,298,234.56 kWh. This potential continues to increase along with the increasing amount of waste entering the landfill. Based on the results of research by Nina Angriani and Ansar Suyuti in 2017, it is recommended that the waste processing system be an advanced product in the form of electrical energy in the Puwatu landfill can be applied in other landfills. Good waste management in addition to reducing 
environmental problems, can provide economic benefits for managers, government, and society. It is necessary to study and analyze the benefits and costs that may arise from the development of Puwatu landfill electricity and how the development strategy [3].

The existence of waste power plants in the Puuwatu landfill that has been running for about 10 years should have increased in terms of electrical energy generated from processing organic waste into methane gas used to run the power generation engine. For this reason, we intend to conduct a study entitled "Analysis of the use of electricity generated from methane gas produced by organic waste treatment" [4]

More than half of that trash ends up in land ills where it generates methane, a greenhaouse gas thats over 20 times more potent than carbon dioxida. This methane from waste can be used to produce energy [5].

The problem of solid waste management has been increased due to rapid increase of population, intensive agriculture and industrialization. Accumulation and improper methods of disposal of waste, including heaping, dumping, land filling and incineration, cause pollution and hazards to human and environmental health [6]. The environmental aspect of the biomass power also has been an interesting object discussed in some studies [7].

The problem formulation of this research is how much methane gas is produced from the amount of waste in Puuwatu Landfill and How much electricity is generated from the amount of methane gas produced [8]. The purpose of this study was to determine the amount of methane gas produced from the amount of waste in the Puuwatu landfill and to determine the amount of energy obtained from the amount of methane gas available.

\section{Literature Review}

\subsection{Trash}

Garbage is a material that is wasted or thrown away from the source of the results of human and natural activities that do not yet have economic value. As for the definition of waste, it is waste that is unwanted residual material after the end of a process. In most of the recent EU member countries, as well as Spain and Greece, instead, sanitary landfilling is still the mostadopted waste management strategy $(>50 \%)[9]$.

\subsection{Organic Waste}

Organic waste is waste that can be decomposed by microorganisms or can rot like household waste in the form of food scraps and natural waste in the form of leaves and wood. The municipal solid waste (MSW) generated by households is considered the third largest anthropogenic source of methane $\left(\mathrm{CH}_{4}\right)$ emissions, constituting $11 \%$ of all global $\mathrm{CH}_{4}$ emissions [10]. 


\subsection{Methane Gas}

Methane gas in English Methane gas with the chemical element $\mathrm{CH}_{4}$, is a major component of biogas. Methane gas is the simplest hydrocarbon compound in the form of gas. The properties of methane gas [11]:

1. Chemical Properties: Molecular weight 16, Freezing point 900 C, Boiling point 111.7, Critical point 190, Critical pressure, Critical volume $99.0 \mathrm{~cm} / \mathrm{g}$ mol

2. Physical Properties: Is a gas that is flammable, odorless, is a colorless gas, has a specification of a flame of $500-700 \mathrm{k} . \mathrm{cal} / \mathrm{m}^{3}$. So, methane is both odourless and colourless [12].

Methane has been rising rapidly in theatmosphere over the past decade, contributing to global climate change. Methane is the second most important greenhouse gas behind carbon dioxide causing global climate change, contributing approximately $1 \mathrm{Wm}^{-2}$ to warming when indirect effects are included compared to $1.66 \mathrm{Wm}^{-2}$ for carbon dioxide [13].

Atmospheric methane levels rose steadily during the last few decades of the 20th century before leveling off for the first decade of the $21^{\text {st }}$ century. Since 2008, however, methane concentrations have again been rising rapidly. This increase, if it continues in coming decades, will significantly increase global [14].

\subsection{Calculation of Biogas Energy Capasity From Waste Raw Materials}

1. Amount of total Solid (TS), Volatile Solid (VS). and Biogas Production

Based on the results of testing by Tanya Mc.Donald, Gopal Achari, and Bimbola Abiola in the article "Feasibility of Increased biogas production from the co-division of agricultural, municipal, and agro-industrial wastes in rulal communities". By testing biogas production made from organic waste, the conversion value of organic waste to Total Solid (TS) and Volatile Solid (VS) is obtained, as shown in Table 1 below. In this literature the value of VS is equivalent to the value of biogas produced.

Table 1. Potential Total Solid (TS), Volatile Solid (VS) and Biogas Production of organic wast [15]

\begin{tabular}{llll}
\hline Material Type $(\mathrm{kg})$ & Total Solid (TS) (\%) & Volatile Solid (VS) $(\%)$ & $\begin{array}{l}\text { Biogas Production } \\
\left(\mathrm{m}^{2} / \mathrm{kg} \mathrm{TS}\right)\end{array}$ \\
\hline Organic Trash & 27.7 & 74.1 & 0.676 \\
\hline (Source: Agung Sulistiyo, 2010).
\end{tabular}

Based on the table above, the equation for calculating Total Solid, Solid Volatile, and biogas production is as follows [15]:

$\mathrm{TS}=27.7 \% \times \mathrm{Q}$ (1)

$\mathrm{VS}=74.1 \% \times \mathrm{TS}(2)$

$\mathrm{VBS}=0.676 \times \mathrm{VS}(3)$

Information:

$\mathrm{Q}=$ Waste Potential ( $\mathrm{kg} /$ day)

$\mathrm{TS}=$ Total Solid 
$\mathrm{VS}=$ Volatile Solid $(\mathrm{kg} /$ day $)$

VBS $=$ Volume of biogas production $\left(\mathrm{m}^{3} /\right.$ day $)$

2. Amount of Methane Gas Produced

To calculate the amount of potential methane gas produced in a landfill process.

Table 2. Amount of volume of methane gas from organic waste

\begin{tabular}{ll}
\hline Biogas Production $\left(\left(\mathrm{m}^{3} /\right.\right.$ day $)$ & Amount of methane gas $(\%)$ \\
\hline VBS & 60 \\
\hline Source: Agung Sulistyo, 2010) &
\end{tabular}

Based on the table above, the equation for calculating gas is:

$\mathrm{VGM}=60 \% \mathrm{x}$ VBS (4)

Information

VGM $=$ Volume of methane gas $\left(\mathrm{m}^{3} /\right.$ day $)$

VBS $=$ Volume of biogas production $\left(\mathrm{m}^{3} /\right.$ day $)$

3. The Potential of Electrical Energy Produced

The potential of methane gas in $\mathrm{m}^{3}$ must be equalized in units of electrical energy (kWh). In the book Renewable Energy Conversion, Transmission Storage, by Bent Seronsen, $1 \mathrm{~m}^{3}$ of methane is equivalent to $6.13 \times 10^{7}$ Joules, while $1 \mathrm{kWh}$ is equivalent to $3.6 \times 10^{7}$ Joules. So that $1 \mathrm{~m}^{3}$ of methane produces electricity of $9.36 \mathrm{kWh}$.

Table 3. Energy conversion of methane gas into electrical energy [15]

\begin{tabular}{ll}
\hline Type of Energy & Equivalent Energy \\
\hline $1 \mathrm{Kg}$ Methane gas & $6.13 \times 10^{7}$ Joule \\
$1 \mathrm{kWh}$ & $3.6 \times 10^{7}$ Joule \\
$1 \mathrm{~m}^{3}$ Methane gas & $9.9 \mathrm{kWh}$ \\
\hline
\end{tabular}

(Source: Agung Sulistyo, 2010)

\section{Research Methods}

This research is a descriptive study with a quantitative approach, which was conducted at Puuwatu Landfill in Kendari City. Yusuf, 2013, stated that the descriptive method was a conscious and systematic effort to provide answers to a problem and / or obtain more in-depth and extensive information on a phenomenon by using quantitative research stages. In this case, to calculate the potential methane waste in Puwatu Landfill, Types and Sources of Data In this study include primary data and secondary data. Primary Data is data obtained directly at the research location. This data was obtained from field observations and through informant interviews. Primary data sources were obtained from the Puwatu Landfill, the Sanitation, Parks and Cemeteries Office of Kendari City, and the Southeast Sulawesi Province BAPPEDA. The primary data needed is the composition of waste in the Puwatu landfill, the volume of waste, the waste management policy in Kendari City and the regional energy 
development policy. Secondary data obtained through various sources of written reports, libraries and other documents. Secondary data sources are the City of Sanitation, Parks and Cemeteries Office of Kendari City, BPS Office, and from literature studies. Secondary data needed includes population data (population, population growth) and waste management data. In addition, secondary data was also obtained from documents relating to the use of landfill gas as energy. The calculation is done using references from the library.

\section{Data Analysis}

\subsection{Data on waste volume from January to July 2018}

It is obtained from the TPA Puuwatu Unit Pelaksana Teknis (UPTD) as follows:

Table 4. Amount of waste volume per month

\begin{tabular}{lc}
\hline \multicolumn{1}{c}{ Month 2018 } & Volume $\mathrm{m}^{3}$ \\
\hline January & $4,950.5$ \\
February & $4,410.0$ \\
March & $4,560.0$ \\
May & $6,330.5$ \\
June & $5,892.5$ \\
July & $6,523.5$ \\
\hline Total & 32,667 \\
\hline
\end{tabular}

\subsection{Biogas Energy Capacity from Materials Raw Waste} month.

Calculation of biogas energy capacity from waste raw material in Puuwatu landfill per

1. January 2018

For conversion from $\mathrm{m}^{3}$ to $\mathrm{Kg}$ then at times with 169.44 , so:

$4950.5 \mathrm{~m}^{3}$ equivalent to $=4950.5 \times 169.44$

$$
\begin{aligned}
& =838,812.7 \mathrm{Kg} / \text { Month } \\
& =838,812.7 / 30 \text { days } \\
& =27,960.424 \mathrm{Kg} / \text { Day }
\end{aligned}
$$

$$
\begin{aligned}
\mathrm{TS} & =27.7 \% \times \mathrm{Q} \\
& =27.7 \% \times 27,960.424 \\
& =7,745.037448 \mathrm{~kg} \\
\mathrm{VS} & =74.1 \% \times \mathrm{TS} \\
& =74.1 \% \times 7,745.037448 \mathrm{~kg} \\
& =5,739.0727 \mathrm{~kg} \\
\mathrm{VBS} & =0.676 \times \mathrm{VS} \\
& =0.676 \times 5,739.0727 \mathrm{~kg} \\
& =3,879.613 \mathrm{~m}^{3}
\end{aligned}
$$

For details, from January to July can be seen in the following table: 
Table 5. Q and VBS values

\begin{tabular}{lll}
\hline Month & $\mathrm{Q}(\mathrm{kg} /$ day $)$ & $\mathrm{VBS}\left(\mathrm{m}^{3}\right)$ \\
\hline January 2018 & $27,960.424$ & $3,879.613$ \\
February 2018 & $24,907.68$ & $3,456.0336$ \\
March 2018 & $25,754.88$ & $3,573.5857$ \\
May 2018 & $35,754.664$ & $4,961.0931$ \\
June 2018 & $33,280.84$ & $4,617.8414$ \\
July 2018 & $36,844.728$ & $5,112.3435$ \\
\hline TOTAL & $184,503.22$ & $25,600.5103$ \\
\hline
\end{tabular}

\subsection{Methane Gas Production}

Energy production in biogas is comparable to the production of methane gas $\mathrm{VGM}=60 \% \times \mathrm{VBS}$

Information:

$\mathrm{VGM}=$ Methane gas production $\left(\mathrm{m}^{3} /\right.$ day $)$

$\mathrm{VBS}=$ Volume of biogas production $\left(\mathrm{m}^{3} /\right.$ day $)$

1. January 2018

$\mathrm{VBS}=3,879.613 \mathrm{~m}^{3}$

$\mathrm{VGM}=60 \% \times \mathrm{VBS}$

$$
\begin{aligned}
& =60 \% \times 3,879.613 \\
& =2,327.7678 \mathrm{~m}^{3} / \text { day }
\end{aligned}
$$

For details, from January to July can be seen in Table 6

Table 6. Methane Gas Production Value (VGM)

\begin{tabular}{lll}
\hline Month year & VBS $\left(\mathrm{m}^{3}\right)$ & VGM $\left(\mathrm{m}^{3}\right) /$ day \\
\hline January 2018 & $3,879,613$ & $2,327.7678$ \\
February 2018 & $3,456.0336$ & $2,073.6202$ \\
March 2018 & $3,573.5857$ & $2,144.1514$ \\
May 2018 & $4,961.0931$ & $2,976.6559$ \\
June 2018 & $4,617.8414$ & $2,770.7048$ \\
July 2018 & $5,112.3435$ & $3,067.4061$ \\
\hline TOTAL & $25,600.510$ & $15,360.3062$ \\
\hline
\end{tabular}

\subsection{Electricity Energy Produced}

From Table $3,1 \mathrm{~m}^{3}$ of methane gas equals $9.39 \mathrm{kWh}$

$\mathrm{E}=\mathrm{VGM} \times \mathrm{FK}$ (Correction Factor)

$$
=\text { VGM } \times 9.39
$$

1. January 2018

$\mathrm{VGM}=2,327.7678 \mathrm{~m}^{3} /$ day

$\mathrm{E}=\mathrm{VGM} \times 9.39$

$$
=2,327.7678 \times 9.39
$$$$
=21,857.7396 \mathrm{kWh}
$$

For details, from January to July can be seen in the following table: 
Table 7. VGM and Electric Energy Value

\begin{tabular}{lll}
\hline Month 2018 & VGM $\left(\mathrm{m}^{3}\right)$ & $\mathrm{E}(\mathrm{kWh})$ \\
\hline January & $2,327.7678$ & $21,857.7396$ \\
February & $2,073.6202$ & $19,471.2933$ \\
March & $2,144.1514$ & $27,950.7905$ \\
May & $2,976.6559$ & $27,950.7905$ \\
June & $2,770.7048$ & $26,016.9184$ \\
July & $3,067.4061$ & $28,802.9433$ \\
\hline Total & $\mathbf{1 5 , 3 6 0 . 3 0 6 2}$ & $\mathbf{1 4 4 , 2 3 3 . 2 6 6 6}$ \\
\hline
\end{tabular}

Amount of electrical energy in year:

E Year $=$ E Total $\times 2$

$$
\begin{aligned}
& =144,233.2666 \mathrm{kWh} \times 2 \\
& =288,466.5332 \mathrm{kWh}
\end{aligned}
$$

\subsection{Estimated Electricity Energy}

Estimates in the daily average value from January to July 2018, the energy produced from the Puuwatu landfill in the daily average is $288,466.5332 \mathrm{kWh}$. Whereas the energy flowing through the Independent Energy area the number of houses is 125 houses and each house has 450 VA (2 Ampere MCB), then the daily count used to fulfill the energy independent region is as follows:

$$
\begin{aligned}
125 \times 360 \text { watts } & =45,000 \text { watts } \\
& =45 \mathrm{kw} \times 24 \text { hours } \\
& =1,080 \mathrm{kWh}
\end{aligned}
$$

So that the untapped energy from the potential at Puuwatu Landfill is as big as:

$\mathrm{E} \mathrm{Not}=288,466.5332 \mathrm{kWh}-1,080 \mathrm{kWh}$

$=287,386.5332 \mathrm{kWh}$

\section{Conclusion}

The conclusion obtained from this study is the amount of methane gas produced from the annual Puuwatu landfill is $15,360.3062 \mathrm{~m}^{3}$ and the amount of energy generated is $288,466.5332 \mathrm{kWh}$.

Compared to other big cities in Indonesia, the amount of methane gas acquisition in Puuwatu Kendari City is very small. This is very much determined by the amount of rubbish produced by the people of Kendari City, which only ranges from hundreds of tons per day compared to big cities like Surabaya, Palembang, Makassar, Bandung, Bekasi, with an average of 1500 tons to 2800 tons per day.

So, it is very natural that the government, in this case the Ministry of Energy and Mineral Resources, has launched the construction of a Waste-Generated Power Plant in several cities that produce very large amounts of waste per day between 1500 tons per day to 2800 tons per day. And not including the city of Kendari. 


\section{References}

[1] Damanhuri and Padmi, 2010. Diktat Lecture TL-3104, Waste Management, Environmental Engineering Study Program Faculty of Civil and Environmental Engineering, Bandung Institute of Technology (ITB) Semester I Edition - 2010/2011.

[2] Kaza S, Yao L, Bhada-Tata P, Van Woerden F (2018) What a waste 2.0: a global snapshot of solid waste management to 2050. World Bank Publications. https ://openk nowle dge.world bank.org/handl e/10986/2174.

[3] Sanitation White Paper Kendari City, 2011. PPSP Kendari City, 2011

[4] Guidebook, 2011, Renewable ENERGY, (This book is compiled with funding from the Royal Danish Embassy).

[5] Nazlie Haq A, et al. Study of Waste Power Plant in Banjarmasin City. [Journal]. Semarang: Diponegoro University; 2012.

[6] Cho, Renee. E : the Environmental Magazine; May/Jun 2011; 22, 3; Biological Science Collection pg. 12.

[7] Aditya Rachman, et.all. The potential of delivering clean locally available limitless rice husk energy in the Celebes Island Indonesia. 2015. Intemational Conference on Alternative Energy in Developing Countries and Emerging Economies.

[8] Puneeta Dandotiya. Et.all. AN ECO-FRIENDLY MANAGEMENT OF HOUSEHOLD ORGANIC WASTE. Entomology Research Unit, School of Studies in Zoology, Jiwaji University, Gwalior, M.P. 474011. *Corresponding author's E-mail: dpuneeta@gmail.com. Received: 23rd April 2015 Revised: 9th May 2015 Accepted: 16th May 2015.

[9] Francesco Lombardi1. Et.all. Analysis of the role of the sanitary landfill in waste management strategies based upon a review of lab leaching tests and new tools to evaluate leachate production. doi:10.4136/ambi-agua.2096. Received: 15 Feb. 2017; Accepted: 10 May 2017.

[10] Chander Kumar Singh , Anand Kumar \& Soumendu Shekhar Roy, 2018. Quantitative analysis of the methane gas emissions from municipal solid waste in India.

[11] A. Djohar and M. Hasyim, 2016, Study of Puuwatu Waste Power Plant (PLTSa) with Sanitary Landfill Technology in the Puuwatu City Final Waste Management Site (TPAS) of Kendari. (Proceedings of the National Seminar on Energy and Electricity Engineering-SNTEK 2016).

[12] Fabio De-Giorgio, et all. Homicide by methane gas. Forensic Science International 221 (2012) e1-e3. journal homepage: www.elsevier.com/locate/for sciint.

[13] IPCC: Climate Change 2013: The Physical Science Basis. Contribution ofWorking Group I to the Fifth Assessment Report of the Intergovernmental Panel on Climate Change, Intergovernmental Panel on Climate Change, chap. 8, 659-740, 2013.

[14] Nisbet, E. G., et all. Very strong atmospheric methane growth in the 4 years 2014- 2017: implications for the Paris Agreement, Global Biogeochem. Cy., 33, 318-342, https://doi.org/10.1029/2018GB006009, 2019.

[15] Sulistyo A. Analisis Manfaat Sampah Organik Sebagai Bahan Baku Biogas di Pasar Induk Keramat Jati.[Tesis]. Depok : Universitas Indonesia ; 2010. 